\title{
An Assessment Approach to Circular Business Models within an Industrial Ecosystem for Sustainable Territorial Development
}

\author{
Leyla Gamidullaeva ${ }^{1, *(\mathbb{D}}$, Nadezhda Shmeleva $\left.{ }^{2}{ }^{(}\right)$, Tatyana Tolstykh ${ }^{3,4}\left[\right.$ and Alexey Shmatko ${ }^{5}$ \\ 1 Department of Management and Economic Security, Penza State University, 440026 Penza, Russia \\ 2 Department of Economics, National University of Science \& Technology (MISIS), 119049 Moscow, Russia; \\ nshmeleva@misis.ru \\ 3 Department of Industrial Strategy, National University of Science \& Technology (MISIS), \\ 119049 Moscow, Russia; tt400@mail.ru \\ 4 Department of the Industrial Economics, Plekhanov Russian University of Economics, 119049 Moscow, Russia \\ 5 Institute for Regional Economic Studies, Russian Academy of Sciences, 190013 Saint Petersburg, Russia; \\ shmat2000@yandex.ru \\ * Correspondence: gamidullaeva@gmail.com
}

Citation: Gamidullaeva, L.; Shmeleva, N.; Tolstykh, T.; Shmatko, A. An Assessment Approach to Circular Business Models within an Industrial Ecosystem for Sustainable Territorial Development. Sustainability 2022, 14, 704. https:// doi.org/10.3390/su14020704

Academic Editor: Petri Ahokangas

Received: 4 December 2021

Accepted: 7 January 2022

Published: 9 January 2022

Publisher's Note: MDPI stays neutral with regard to jurisdictional claims in published maps and institutional affiliations.

Copyright: (c) 2022 by the authors. Licensee MDPI, Basel, Switzerland This article is an open access article distributed under the terms and conditions of the Creative Commons Attribution (CC BY) license (https:// creativecommons.org/licenses/by/ $4.0 /)$.

\begin{abstract}
In this work, the authors have made an attempt to develop a methodological approach to substantiate the socio-economic efficiency of enterprise performance within an industrial ecosystem in the context of a circular economy. The proposed approach has been verified via a case study of the industrial ecosystem in Novokuznetsk city. Based on the calculations, it has been evidenced that the creation of an industrial ecosystem in the region where the city is located would eliminate area sources of pollution and improve the quality of life of the population, which would advance regional sustainable development and strengthen territorial attractiveness for citizens. Thus, having used the proposed methodology, the prospects for the implementation of circular business models by enterprises in order to increase the efficiency of resource use and balanced and sustainable economic development of a territory have been substantiated. The transition to a circular economy can support the creation of favorable environmental conditions and increase the local community resilience, well-being, and quality of life.
\end{abstract}

Keywords: sustainable development; regional development; industrial ecosystem; urban ecosystem; circular economy; cluster

\section{Introduction}

Currently, there is an extensive development of a circular economy (CE) concept and its integration into existing socio-economic systems worldwide.

A circular economy has evolved as a new paradigm to consider the prospects for economic development with a potential of achieving carbon neutrality by 2050 [1].

Various international organizations (OECD, EU) and countries have already elaborated their own CE development programs [2-5].

However, according to a European Environment Agency report [6], circular economy initiatives in Europe are still at an early stage. European Union Member States face a dilemma on how to deal with the millions of tons of waste generated in Europe every year.

There has been a constant and unprecedented growth in the demand for raw materials worldwide over the past 50 years [7]. During this period, world production of goods has doubled, extraction of materials has tripled, and economic growth measured by GDP has quadrupled. This increased activity has led to the loss of over $90 \%$ of biodiversity and water scarcity, and has made a significant contribution to climate change. The consumption of raw materials is likely to have increased from 92 to almost 190 billion tones by 2060 globally, while greenhouse gas emissions could grow by 43\% [7]. According to forecasts, it is 
expected that the volume of consumed raw materials and supplies should grow with simultaneous increase in resource efficiency $[7,8]$.

An exponential growth of production and consumption waste leading to social and environmental problems is considered to be a challenging issue in the formation of a circular economy in Russia and the EU [9].

In 2020, according to the Federal Service for Supervision of Natural Resources, there were 5.4 billion tons of industrial and household wastes in the Russian Federation. Industrial (primarily, mining) wastes accounted for almost $90 \%$ of the total waste generation. The manufacturing sector accounted for $10 \%$ of any hazardous wastes generated in the Russian Federation. The textile production and metallurgy were regarded as the most pollution-intensive industries (5\% and 4\%, respectively, of the total generation for 2020).

According to the data from the Ministry of Natural Resources and Environment of the Russian Federation for 2020, about 70 million tons of Class IV and V hazardous mixed municipal solid wastes (MSW) are generated in Russia annually. MSW generation grows by $3 \%$ yearly, having been doubled for 20 years [10].

At present, the situation in the sphere of waste management is radically changing in the Russian Federation. The main goal of the Strategy for the development of industry for processing, utilization, and neutralization of production and consumption waste for the period until 2030 [11] is establishing and developing the industrial sector for recycling and disposal of waste, ensuring maximum utilization of waste in production and systematic reduction of the amount of unused waste, based on the $3 R$ principle (reduce waste generation, reuse, and recycle to recoverable resources).

This goal implies a transition from a linear model of the economy to novel circular business models and upscaling thereof globally. Meeting circular economy goals (reducing, reusing, and recycling) requires innovation in the type of business model used, technological innovation and social innovation (new ways of interacting or connecting business and people). Improved circular and climate-friendly business models and policies to boost reuse and recycling, plus improved consumer awareness will help tackle the growing problem.

To ensure circularity, increase in the efficiency of resource use and sustainable development of the economy and society as a whole, the flows of material resources should be significantly transformed at the system level. These systemic transformations will require the direct involvement and close interaction of various enterprises and organizations, institutions, authorities, consumers, and individuals. In order to implement such a systemic interaction, the ecosystem concept seems to be the most able to explain the transition of linear models to circular ones, which are resource flows along the feedback lines between various actors that provide resource efficiency.

Major environmental issues related to industrial regions of the Russia are concerned with the following issues [12]:

- $\quad$ increasing the negative impact on the environment caused by higher emissions of pollutants into the atmosphere;

- a significant number of industrial enterprises exceed the maximum permissible impact limits (emissions, discharges);

- low level of use and recycling of production and consumption waste, etc.

Creating conditions for territorial sustainable development and ensuring regional environmental well-being through the establishment of partnerships and the development of long-term and effective cooperation aimed at the elaboration and implementation of circular business models, principles, and approaches to the implementation of industrial ecosystems in the Russian regions will allow solving a number of social, environmental, and economic problems. Reuse and recycling are the key guidelines to tackle Russia's waste problem and to foster a more circular economy.

The remainder of this article is organized as follows. Section 2 provides a theoretical overview of perspectives on the use of interrelated concepts of a circular economy and an ecosystem approach to foster implementation of sustainable business models in the economic practice. Theoretical foundations of our research and outlines of the industrial 
ecosystem approach in the circular economy settings are also presented here. Section 3 presents a methodology for assessing resource efficiency based on the theory of competence by T. Gilbert. Next, in Section 4, we consider the proposed methodological approach illustrated by a specific industrial ecosystem in Novokuznetsk. The presented results based on the empirical analysis are discussed in Section 5. Section 6 focuses on the key research findings, presents the theoretical contribution and practical significance of the study, and dwells on the limitations of the conducted research.

\section{Literature Review}

The circular economy is fundamentally the opposite of the current take-make-consumedispose linear economic model. The linear model, based on the assumption that natural resources are available, abundant, readily available, and cheap to utilize, is not sustainable, since humanity is approaching the limit of the planet's ability to provide resources, in some cases having already transgressed thereof [13].

The Ellen MacArthur Foundation [14] has defined a circular economy as an economy focused on recovery and aimed at preserving the beneficial properties and value of products, components, and materials. This minimizes the need for new material and energy resources while reducing the negative impact on the environment from resource extraction, emissions, and waste. Such a model goes beyond simple waste management and requires the efficient and rational use of natural resources throughout their entire life cycle. The circular economy offers the opportunity to create added value, growth, and jobs while reducing pollution. Actually, this concept can be applied to all types of natural resources, including biotic and abiotic materials, water, and land resources.

Eco-design, product sharing, repair, recovery and reuse, waste prevention, and recycling are the key elements of a circular economy. Although the loss of materials due to their disposal and incineration is reduced, these methods are likely to play a role in the safe removal of hazardous substances from the biosphere and the recovery of energy from non-recyclable waste at a much lower level.

There are various concepts and theoretical constructs for understanding a circular economy [15-17]. The main idea is that waste generation and material use are minimized through eco-design, waste recycling, and product reuse. This creates both economic and environmental benefits, as dependence on mining and imports decreases in parallel with reducing emissions to the environment, for example, from the extraction and processing of materials, incineration, and disposal of waste. However, practical implementation of the CE model contributes to the achievement of the sustainable development goals adopted by the UN [18].

The outer circle represents energy flows, and the related parameters are overall energy efficiency and the share of renewable energy sources. The energy obtained from waste incineration can partially offset the use of (fossil) fuel and energy resources, but the use of this utilization method should still be minimized, since the energy obtained from incineration can only be used once, and thus, materials are removed from the circulation.

The middle circle represents material flows in the recycling cycle, and it distinguishes between abiotic technical materials (such as metals and minerals) and biotic ones.

The inner circle represents such processes as reuse, redistribution, repair, restoration, and modernization, which allow one to prevent waste generation and dispense with their recycling; that is, to minimize resource use. These approaches keep the value of products, components, and materials at the highest possible level. However, the key to achieving the necessary systemic change will be the creation of synergistic economic and social incentives, for example, through financial mechanisms that encourage consumers and manufacturers to rent rather than buy a product, while taking action to promote the eco-design of the product.

Building a circular economy requires fundamental changes at all stages of the value chain: from product design and manufacturing technology to new business models, new ways of conserving natural resources (extending the life of products) and converting waste 
into a resource (recycling), new forms of consumer behavior, updating standards and practices, and education and finance.

Consistency among the participants of the value chains and between the participants and the environment is also essential. Proactive action is required from all stakeholders, including governments, business, academia, civil society, and individuals.

A linear take-make-consume-dispose approach leads to a significant burden on the environment and human health, and may also reduce the potential for increasing the competitiveness of a number of industries. A circular economy, in contrast, could provide a platform for innovative approaches in technology and business models to create more value added with fewer natural resources and provide significant cost savings for various industries.

Social innovation through sharing, eco-design, reuse, recycling, and other processes will lead to more rational consumer behavior while promoting human health and safety.

To organize the transition to a circular economy with the economic growth to be achieved regardless of consumption rate of natural resources, novel approaches to management in the form of the so-called circular business models (CBM) are required along with the optimization of existing processes.

To fully exploit the potential for the circular economy transition, the business models should be both rational and scalable. To do this, it is necessary to study the best practices, look for new organizational and economic mechanisms that allow the management of companies to more effectively implement the CBM, develop and improve standards in the field of sustainable development, and improve methodological approaches to assessing the effectiveness of the implementation of circular economy principles in terms of material flows and business models [19].

As already mentioned above, the efforts of a single enterprise are not enough to introduce the circularity principles and increase resource efficiency at the micro-, meso-, and macro-levels. The implementation of recycling technologies at individual enterprises is complicated due to high resource costs and low economic efficiency thereof. These systemic transformations will require direct participation and close interaction based on the ecosystem principles of many enterprises and organizations to ensure the achievement of the strategic goals of each individual participant.

The interdependence of actors within an ecosystem stems from a common institutional environment, common goals, a common process of value creation, or is built on the basis of a technological platform that brings together participants for close interaction and cooperation $[20,21]$. In our research, we have defined the concept of an "ecosystem" as a self-developing system open to external challenges, functioning on the basis of cross-border equal interaction of enterprises of various industries, scientific and state organizations through the exchange of "energy", being new technologies, information, or unique resources [22].

The most vivid practical example demonstrating the implementation of circular business models within an industrial ecosystem is Kalundborg Symbiosis (Denmark) [22].

There are different types of ecosystems, such as entrepreneurial, innovative, industrial, sectoral, corporate, urban, knowledge, platform ecosystems, etc. However, some researchers point out the problems of their conceptualization in terms of vague formulations and ambiguity in interpretation $[23,24]$.

The researchers emphasize that circular models are compatible with the existing types of ecosystems. For example, innovation ecosystem in CE settings is considered as "a community of hierarchically independent, yet interdependent heterogeneous set of actors who collectively deliver a sustainable value offering typified by resource recycling, reuse, and/or reduction" [23].

However, taking into account the initial theoretical premises, the circular economy comes from the orthodox theory of ecosystems in biology [25] and, therefore, directly resonates with the concept of an industrial ecosystem, which focuses on the flow of energy and materials between industrial organizations. The concept of the urban ecosystem, like 
the industrial ecosystem, focuses on material resource and energy flows within the physical environment. Both approaches are used by researchers studying the problems of building smart cities, sustainable development, and circular business models (Figure 1).

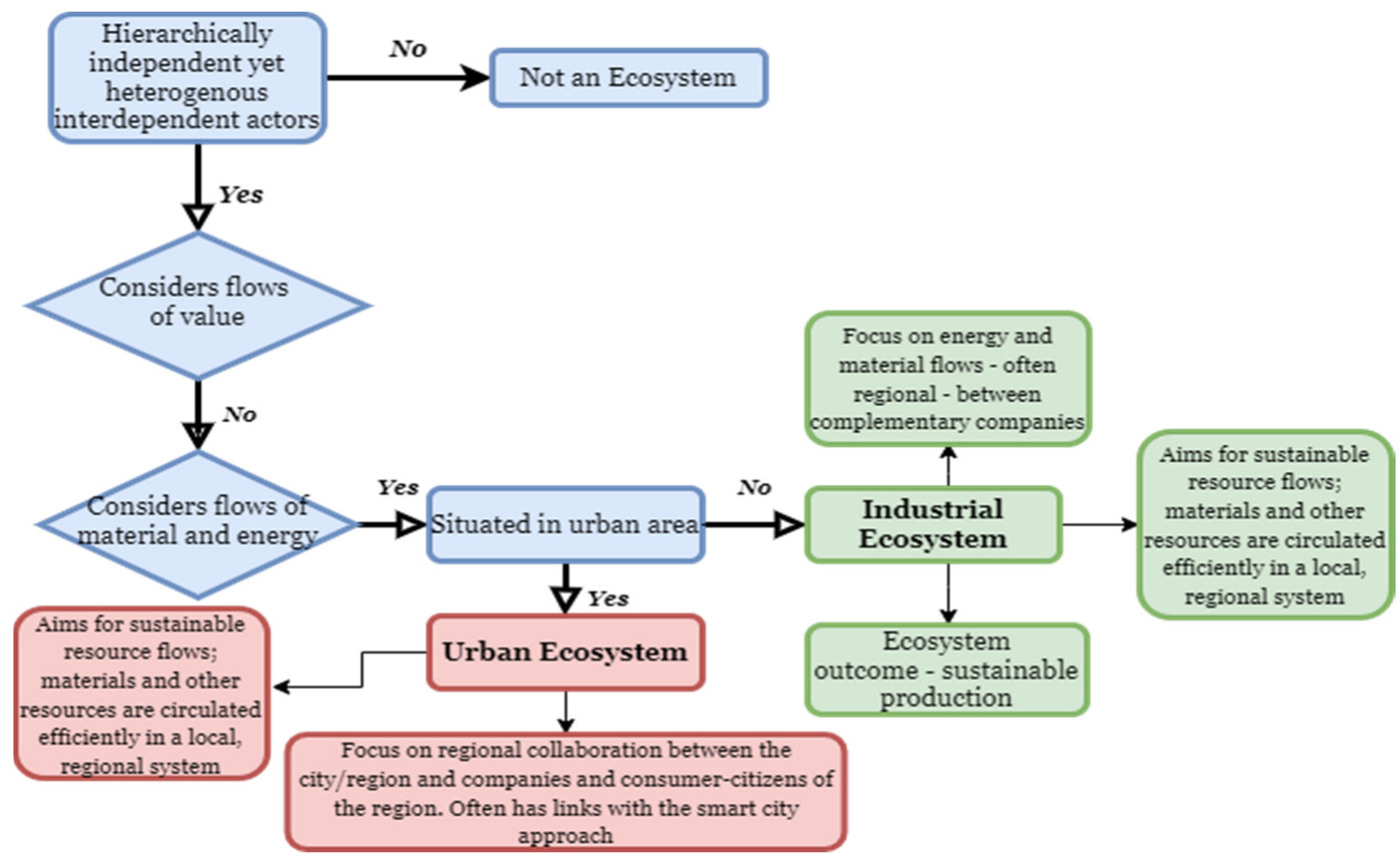

Figure 1. Industrial and urban types of an ecosystem. Source: adapted from [23].

An industrial ecosystem is geographically connected industrial systems in which material and energy flows recycle and generate a sustainable industrial product as a product of the system level [26]. Industrial ecosystems are location dependent as they focus on the development of closed-loop systems that recycle matter in industrial parks or regions $[27,28]$.

According to the authors [23], a circular industrial ecosystem is "a regional community of hierarchically independent, yet interdependent heterogeneous set of actors who sustainably produce industrial goods and services in symbiotic collaboration and resource use." A comparative analysis of industrial and urban ecosystems is presented in Figure 2.

Approaches to the formation of ecosystem models based on recycling

Industrial symbiosis [29], eco-industrial parks [30,31], and industrial ecosystems operating on circularity principles [32] are often regarded as ecosystem models in recycling.

There are various types of environmental innovations acting as "energy" for the formation of industrial ecosystems in CE settings:

$>$ technological innovation;

$>$ social innovation;

$>$ organizational innovation.

Any ecosystem is a multi-actor system in which each actor plays equivalent roles. An actor, technology, or a platform can play the role of a pacemaker (mastermind) or an integrator that unites the ecosystem participants. The pacemaker is to ensure balance and consistency in the interaction among the actors [33-35]. 


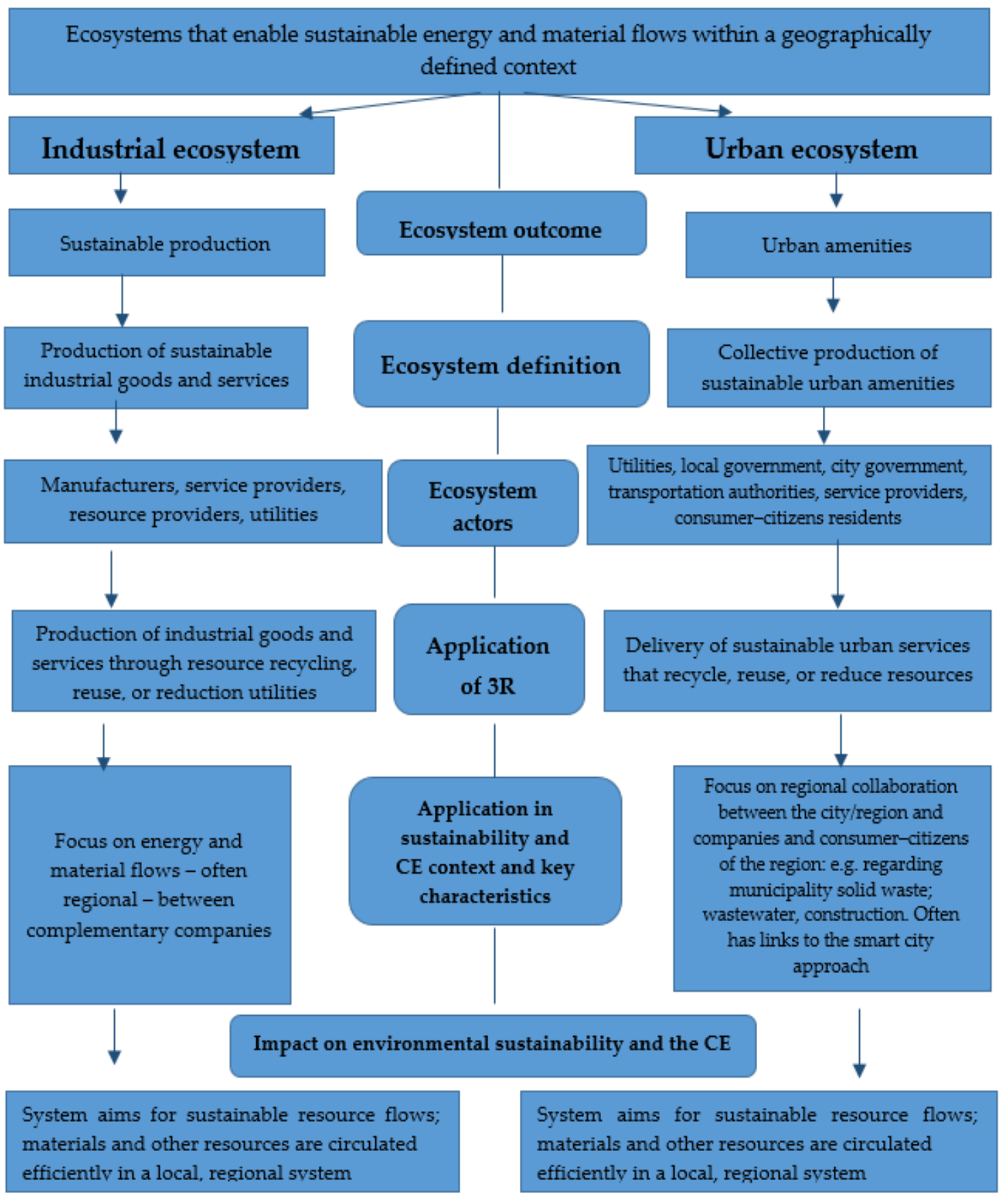

Figure 2. Comparative analysis of industrial and urban ecosystems. Source: adapted from [23].

It is the concept of circularity that is the pacemaker to unite actors of different industries with various levels of a recycling approach in ecosystem models formed on the basis thereof. Here are the main objectives performed by ecosystem models in CE settings:

$\checkmark \quad$ to form the apparent necessity for strategic changes and environmental priorities on micro-, meso-, and macro-levels (see Table 1);

$\checkmark \quad$ to ensure the interaction of interest groups applicable to ecology;

$\checkmark \quad$ to exchange experience and knowledge, to educate and teach;

$\checkmark \quad$ to form monitoring data and indicators for evaluating recycling maturity of an individual actor and the whole ecosystem. 
Table 1. Targets for a circular economy at different management levels.

Levels
Macro-
institutional mechanisms for ensuring a circular economy; collection and assessment
of data on the circularity level of economy
Meso-
Ensuring the interactions of interest groups in the field of ecology; formation of a
system of sectoral and territorial tools for supporting the circular economy;
formation of data that assess the recycling maturity of territories and industries
Introduction of innovative resource-saving and environmental technologies;
implementation of organizational recycling models and approaches; formation of a
motivation system and "green" competencies of employees; formation of
monitoring systems for indicators to evaluate recycling maturity.

Industrial enterprises, service and resource providers, educational institutions, institutes, infrastructure organizations, and other participants can act as actors in industrial ecosystems implementing circular business models. For the most part, the composition of the participants depends on the underpinned circular business model [36-40].

According to the authors, the main approaches to the formation of ecosystem models based on recycling principles are as follows:

$\checkmark \quad$ the use of renewable or secondary materials instead of traditional raw materials. Resource efficiency increases due to the closed-loop material flows. Currently, such business models are used mainly in the production of various consumer goods [41];

$\checkmark \quad$ resource recovery models characterized by converting waste into secondary raw materials. Meanwhile, the material flows are closed through processing, upcycling or cascading, and thereby resource efficiency increases. This business model is especially widespread in the industrial sector [41];

$\checkmark \quad$ business models for product life extension that contribute to the slowdown of material flows in various industries. For example, the service life of cars can be extended by maintenance and repair, and by avoiding planned obsolescence [41];

$\checkmark \quad$ platforms for joint consumption (sharing) aimed at increasing the intensity of using available products through their lease, rental or sharing. Since marketing is aimed at offering usage, rather than possessing specific goods, they contribute to the reduction in resource flows. The sharing economy is presented in many industries, in particular, in the short-term rental housing and transport rental [41];

$\checkmark \quad$ models of product-service systems (PSS), e.g., provision of services instead of products, help reduce resource consumption as well. The customers are given the right to use products being the property of the manufacturer or supplier. This business model is applied, for example, when leasing vehicles [41].

\section{Methodological Framework}

It is essential to apply adequate monitoring indicators and methods for the measurement thereof to create a circular economy and define its goals. There are various indices and indicators in the academic literature and practice of statistical observation worldwide [42-44].

The monitoring framework on the circular economy as set up by the European Commission consists of ten indicators, divided into the following four thematic areas [45]:

$\checkmark$ production and consumption;

$\checkmark \quad$ waste management;

$\checkmark \quad$ secondary raw materials;

$\checkmark$ competitiveness and innovation.

Eurostat is developing an additional indicator for the EU as a whole, raw material consumption (RMC), which provides a better indication of Europe's resource demands from overseas by including the materials used in producing traded goods and resources. Resource productivity is defined as the ratio of GDP to domestic material consumption 
(DMC), i.e., the total amount of materials directly used by an economy, including all physical imports and excluding exports [46].

Here is a set of key indicators for the circular economy used in the Russian Federation:

$\checkmark$ generation and treatment of production and consumption waste;

$\checkmark$ MSW generation per capita as an indicator for consumption efficiency;

$\checkmark$ resource efficiency of the economy as a whole, including material consumption in absolute values and per unit of GDP;

$\checkmark$ resource efficiency of industrial sectors, including material consumption by types of economic activity, indicators for the use of secondary resources and loss of resources in the production process [9].

Resource efficiency has a vital role in facilitating economic development within environmental boundaries, but it also offers broader social and economic gains. These include sustaining non-market ecosystem services (such as purifying air and water), securing supplies of critical resources, increasing competitiveness, and stimulating innovation and job creation. Europe's medium- and long-term strategic planning recognizes the fundamental importance of resource efficiency. For example, the EU's 7th Environment Action Programme (7th EAP) identifies as one of its priority objectives the need to "turn the Union into a resource-efficient, green, and competitive low-carbon economy" [47,48].

The initial premise for the development of this research methodology is that the main goal of creating circular economy is to ensure resource efficiency and resource conservation. The methodology for assessing resource efficiency is based on the theory of competence by $\mathrm{T}$. Gilbert [49]. His theory is based on the idea that people should strive to achieve maximum results with the least possible efforts in order to save opportunities or resources in broad terms. According to Gilbert, the balance method of studying resource efficiency provides a comprehensive coverage of the activities of industrial enterprises and a comprehensive analysis of resource flows.

The authors of this article propose to assess the resource efficiency of industrial ecosystems in terms of material flow balance. Material flow technology is viewed as the process of changing the spatial and temporal position, and the quantitative and qualitative state of its elements (material resources, incomplete production, end product, and production waste).

Production and consumption waste generated at industrial enterprises, as well as waste accumulated from past economic activities, are recycled at specialized enterprises and returned as secondary products to the economy. Thus, a closed-loop waste flow created in the ecosystem can be described mathematically using a system of balance equations.

The balance equation of material flows in the industrial ecosystem is as follows:

$$
\sum X i=\sum Y i+\sum Z i
$$

where $\sum X i$ is the total amount of resources consumed by the actors of the ecosystem;

$\sum Y i$ is the total amount of products produced by the actors;

$\sum Z i$ is the total amount of waste generated by the actors and presented in the environment.

When creating a closed-loop resource flow, the amount of waste generated and presented in the environment should tend to zero, i.e., the waste management system ensures the fulfillment of $\sum Z i \rightarrow 0$ condition. Therefore, recycling involves the generated and accumulated production and consumption waste with further production of secondary raw materials and products based thereon that replace primary raw materials and other technological components of the ecosystem facilities. It is feasible since the waste treatment of industrial enterprises consists of, first of all, the extraction of the components contained therein, being technological value for these industrial enterprises [50].

As a result of the ecosystem functioning, the total amount of waste produced by its actors should be equal to the total amount of secondary resources produced on the basis thereof and the end product:

$$
\sum Z i=\sum X^{\prime} i+\sum Y^{\prime} i
$$


where $\sum Y^{\prime} i$ and $\sum X^{\prime} i$ is the total amount of secondary resources and products made thereof, produced by the enterprises of the ecosystem. Therefore, the balance equation of material flows in the ecosystem will take the form:

$$
\sum X i=\sum Y i+\sum X^{\prime} i+\sum Y^{\prime} i
$$

This equation corresponds to the system of material flows of the ecosystem, created on the basis of circular models of the closed-loop economy. The following modified equation

$$
\sum X i-\sum X^{\prime} i=\sum Y i+\sum Y^{\prime} i
$$

demonstrates that the amount of consumed primary resources decreases by the amount of secondary resources involved in the production process with a simultaneous increase in the total amount of manufactured production in the industrial ecosystem by the amount of products made of secondary resources.

The second approach to assessing the resource efficiency of industrial ecosystems is based on a comparative analysis of indicators for the efficiency of resource usage before and after the entry of enterprises into the ecosystem (e.g., the indicators for material and energy consumption) [9]. The material consumption indicator specifies the development of production processes with higher added value, a change in the structure of production towards declining share of primary sectors of the economy and increasing the share of the service sector, the intensity of consumption of raw materials, and supplies.

The main criterion for energy capacity is a numerical expression being the ratio of energy to the value of the resulted system efficiency (cost of products and services). The indicators are specified in project documentation for products of all types.

Here are the potential criteria for classifying an association of industrial enterprises as a circular industrial ecosystem:

$\checkmark \quad$ an exchange of material and energy resources within the ecosystem;

$\checkmark \quad$ creation of closed-loop water supply systems for the key processes of the ecosystem actors;

$\checkmark \quad$ creation of a common management system for material and energy resources of the ecosystem;

$\checkmark \quad$ using an overall ecosystem infrastructure, including administrative, transport, energy and water supply, and waste management systems.

We consider the proposed methodological approach as a case study of the industrial ecosystem in Novokuznetsk in the next section.

\section{A Case Study: Analysis and Assessment of Industrial Ecosystem (Novokuznetsk) An Analysis of Environmental Problems in Novokuznetsk}

Novokuznetsk monocity is one of the largest industrial centers in Russia, being called the southern capital of Kuzbass. The basis of the industrial sector in Novokuznetsk is formed by metallurgical production, mining, coal enrichment, and conversion (mainly combustion for the purpose of heat and electrical energy production), which account for more than $80 \%$ of the shipped goods and services. The developed industry cannot but influence the environmental conditions in the town. Novokuznetsk is one of the most polluted Russian cities. Enterprises of mining and metallurgical production and heat power engineering (JSC EVRAZ ZSMK, OJSC EVRAZRuda, OJSC RUSAL Novokuznetsk, OJSC Kuznetsk Ferroalloys, four coal preparation plants, three combined heat and power (CHP) plants, over 100 boiler houses) pollute the city with over nine million tons of industrial waste annually [51]. This is $98 \%$ of the total waste, consisting of coal-enrichment waste $(31 \%)$, metallurgical slags $(23 \%)$, ore processing waste $(20 \%)$, municipal solid waste $(2 \%)$, as well as ash and slag waste of CHP plants and boiler houses, refractories, dust, and sludge of gas-cleaning systems, etc. (Figure 3). 


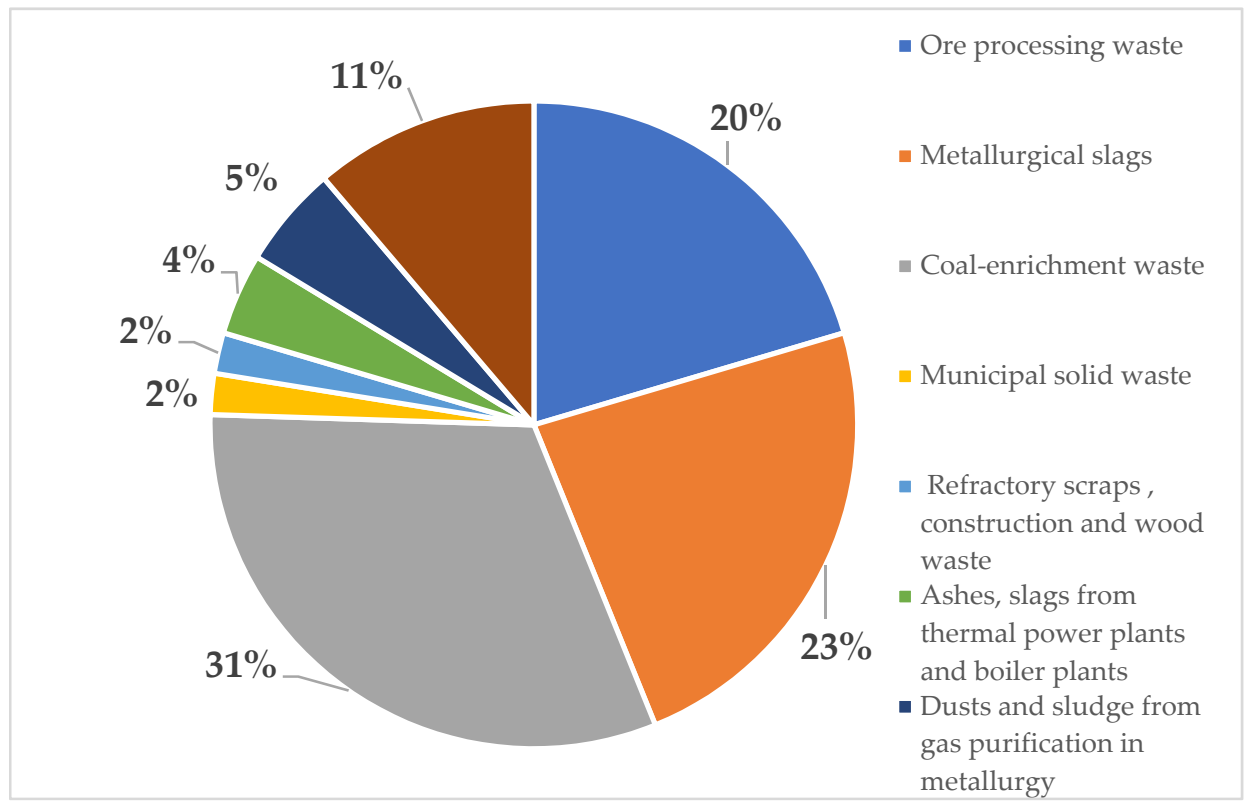

Figure 3. Structure of industrial waste generated in Novokuznetsk. Source: compiled by the authors based on Kuzbass Association of waste recyclers, Novokuznetsk, Russia.

About 300 million tons of various industrial wastes have accumulated on the territory of Novokuznetsk since the first third of the last century. The major accumulators for industrial waste are the tailings storage facilities of ore processing wastes at Abagur Sintering Plant of over 100 hectares, a sludge reservoir at the JSC EVRAZ ZSMK of 300 hectares, metallurgical slag dumps, storage collectors for liquid waste of the coke and by-product process, ash and slag dumps of CHP plants and boiler houses, sludge reservoirs of ferroalloy and aluminum plants, etc. (Figure 4). Every year, hundreds of thousands of dust tons entering the atmosphere of Novokuznetsk and surrounding areas are blown from the surface of dumps and sludge collectors.
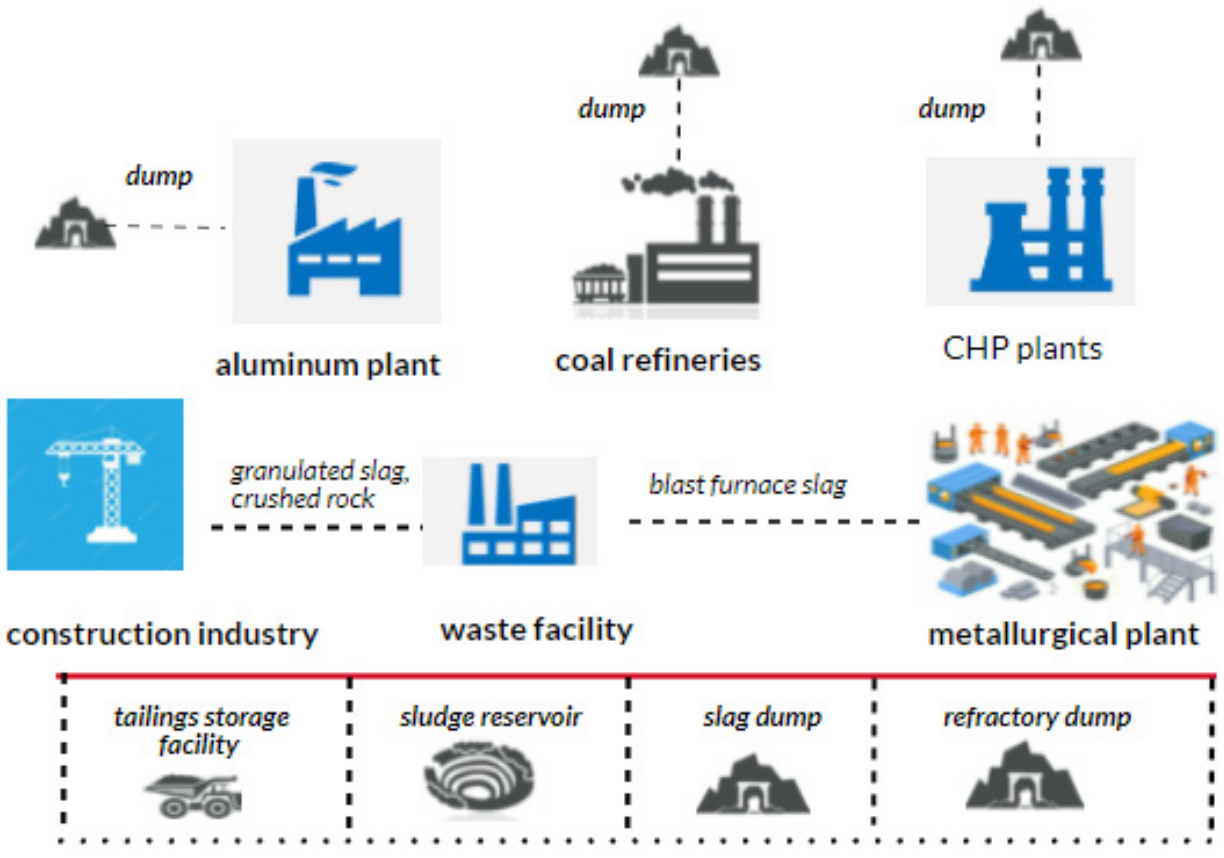

Figure 4. Schematic for industrial waste movement in Novokuznetsk. Source: compiled by the authors. 
The annual dustfall is $409 \mathrm{mg} / \mathrm{m}^{2}$ near the tailings storage facilities of Abagur Sintering Plant. It exceeds the background value of $2 \mathrm{mg} / \mathrm{m}^{2}$ by more than 200 times [52]. The main pollutant in the atmosphere of Novokuznetsk city is benzapilene, which has high carcinogenic activity. In addition to benzapilene, the accumulator contains significant concentrations of other 15 carcinogenic substances. The liquid wastes of the coke and byproduct process located in the "pitch lake" have been evaporating into the atmospheric air for decades and emitting numerous hazardous pollutants, and causing enormous damage to the environment and health of Novokuznetsk residents.

The creation of an innovative industrial ecosystem, specializing in the treatment of industrial waste, could become a solution to environmental and social problems in Novokuznetsk.

\section{Results}

\section{An Assessment of Material Flows within the Circular Industrial Ecosystem of Novokuznetsk}

The ecosystem of Novokuznetsk is an eco-industrial territory where the interaction between the enterprises is being formed and developed on the principles of symbiosis within the framework of circular business models (resource recovery models). Such industrial enterprises as JSC EVRAZ ZSMK, OJSC EVRAZRuda, OJSC RUSAL Novokuznetsk, CHP plants, etc., are the key actors of the industrial ecosystem of Novokuznetsk.

The interaction is based on the principle of industrial symbiosis, when wastes of some enterprise are resources for another one (Figure 5). The waste (slag) from the metallurgical plant is sent to a waste processing facility and, having been processed into granulated slag and crushed rock, is delivered to construction companies. Having been processed, the waste from the aluminum plant is sent to the metallurgical plant in the form of synthetic fluxes and refractory products. The waste from the coal refinery is processed into fuel for thermal power plants and boiler houses, which in turn provide energy and fuel to the metallurgical plant.

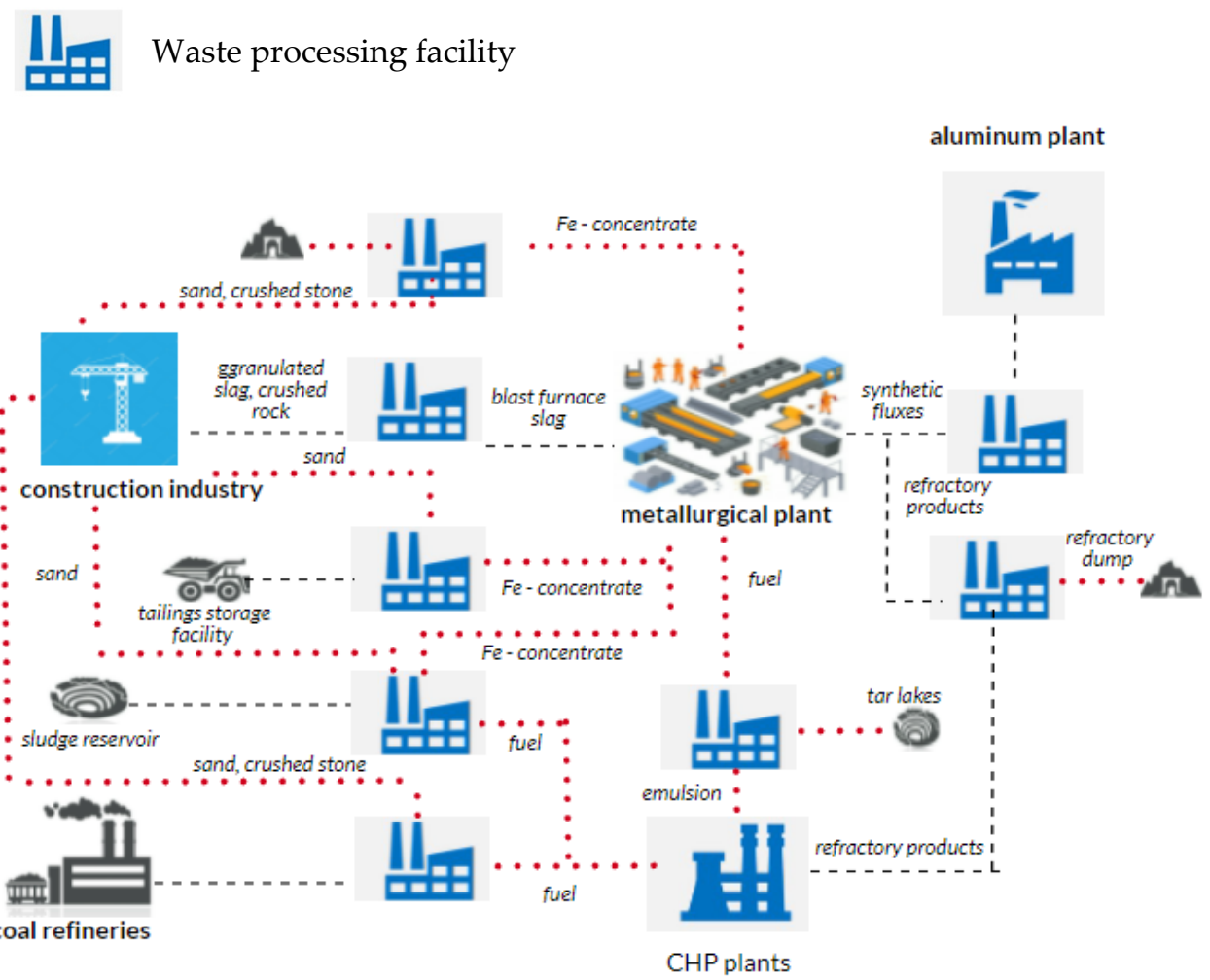

Figure 5. Scheme for industrial waste movement within the industrial ecosystem after the introduction of innovative technologies. Source: compiled by the authors. 
The red dotted lines highlight new material flows between the main actors that are formed in an ecosystem based on the principles of circularity and industrial symbiosis. The black dotted lines represent the material flows and connections that existed between enterprises before joining the ecosystem. Additionally, waste processing facilities were built in the ecosystem for each waste processing technology (Table 2). Before the creation of the ecosystem, the waste-recycling-new product chain was only between the metallurgical plant and construction industry.

Table 2. List of technological solutions for the disposal of industrial waste within the ecosystem.

\begin{tabular}{|c|c|c|}
\hline Waste Processing Technology & $\begin{array}{c}\text { Types of Generated and } \\
\text { Accumulated Production Waste }\end{array}$ & Types of Secondary Raw Materials and Products \\
\hline $\begin{array}{l}\text { Waste processing technology for } \\
\text { iron ore dressing }\end{array}$ & Iron ore dressing waste & $\begin{array}{l}\text { Iron ore concentrate, etalized iron product, pyrite } \\
\text { concentrate, garnet concentrate, sulphide } \\
\text { concentrate, construction sands }\end{array}$ \\
\hline $\begin{array}{l}\text { Coal-enrichment waste processing } \\
\text { technology }\end{array}$ & Coal-enrichment waste & $\begin{array}{c}\text { Coal concentrate, biomass briquettes, ceramic bricks, } \\
\text { construction sands }\end{array}$ \\
\hline $\begin{array}{c}\text { Metallurgical slag processing } \\
\text { technology }\end{array}$ & Metallurgical (steelmaking) slags & $\begin{array}{c}\text { Iron ore concentrate, crushed rock, } \\
\text { construction sands }\end{array}$ \\
\hline $\begin{array}{c}\text { Metallurgical sludge processing } \\
\text { technology }\end{array}$ & Metallurgical (steelmaking) sludges & $\begin{array}{l}\text { Iron ore concentrate, zinc concentrate, } \\
\text { construction sands }\end{array}$ \\
\hline $\begin{array}{l}\text { Liquid waste processing } \\
\text { technology of the coke and } \\
\text { by-product process }\end{array}$ & $\begin{array}{l}\text { Liquid wastes of the coke and } \\
\text { by-product process }\end{array}$ & $\begin{array}{l}\text { Sintering plasticizer for the coke and by-product } \\
\text { process, sleeper impregnation oil, binders } \\
\text { for briquettes }\end{array}$ \\
\hline $\begin{array}{l}\text { Processing of ash and slag waste } \\
\text { of CHP plants and boiler houses }\end{array}$ & $\begin{array}{l}\text { Ash and slag waste of CHP plants } \\
\text { and boiler houses }\end{array}$ & $\begin{array}{l}\text { Ferrous and non-ferrous metal concentrates, } \\
\text { construction materials }\end{array}$ \\
\hline
\end{tabular}

The key objective of the industrial ecosystem in Novokuznetsk is to reduce the amount of consumed primary natural resources and stop environmental pollution. Novel technologies and innovative production for waste and secondary resource treatment have been developed, tested, and implemented within the ecosystem (Table 2).

The technological solutions listed in Table 2 are aimed at increasing the types of recyclable waste and their recycling rate, by forming symbiotic relationships in the ecosystem between the main industrial actors and the use of innovative technologies. In quantitative terms, the dynamics of recycled waste volume can be tracked by indirect indicators presented in Table 3 (in the section on resource efficiency). By direct indicators included in the balance equation - the amount of secondary resources involved in the production process (water, materials, energy), and the cost of products made from secondary resources (iron ore concentrate, crushed stone, construction sands, etc.)

Based on Formula (4), we have drawn up the balance of material flows of industrial enterprises before and after the entry into the industrial ecosystem. On the one hand, the main elements of the material flow of a metallurgical enterprise and mining and processing plant are the costs of raw materials and supplies, energy, and water consumption, i.e., the amount of consumed resources in value terms, and on the other hand, these are the cost of manufactured products and waste of production and consumption. Let us draw up the material balance for JSC EVRAZ ZSMK (metallurgical and coal production segments) and OJSC RUSAL Novokuznetsk (aluminum production) according to the data presented in Tables 3 and 4, respectively. The initial data for the calculations of material flows balance equation (operating and environmental activities) have been based on information from the official reports of the companies (2020 Annual Report, the Sustainable Development Report, Operational and Financial Reports) [53]. Additionally, for the purposes of factor analysis, the authors calculated the capacity indicators in the resource efficiency section. 
Table 3. The results of JSC EVRAZ ZSMK activities for 2019-2020.

\begin{tabular}{|c|c|c|}
\hline Indicators & 2019 & 2020 \\
\hline \multicolumn{3}{|l|}{ Operating activities } \\
\hline Steel production, thousand tonnes & 13,814 & 13,630 \\
\hline Coal production, thousand tonnes & 26,140 & 20,653 \\
\hline Steel sales revenue, million U.S. dollars & 8143 & 6969 \\
\hline Coal sales revenue, million U.S. dollars & 2021 & 1490 \\
\hline Material costs for steel production, million U.S. dollars & 2587 & 2025 \\
\hline Material costs for coal production, million U.S. dollars & 159 & 110 \\
\hline Energy costs in steel production, million U.S. dollars & 439 & 398 \\
\hline Energy costs in coal mining, million U.S. dollars & 51 & 43 \\
\hline \multicolumn{3}{|l|}{ Environmental activities } \\
\hline Metallurgical waste, million tonnes & 8.9 & 9 \\
\hline Cost of metallurgical waste (iron-and-steel scrap), million U.S. dollars & 3316 & 3316 \\
\hline Mining waste (recycled waste), million tonnes & 35.5 & 38.6 \\
\hline Mining waste recycling rate, $\%$ & 38 & 28.5 \\
\hline Water consumption in steel production, million $\mathrm{m}^{3}$ & 164.7 & 162.2 \\
\hline Water consumption in coal mining, million $\mathrm{m}^{3}$ & 32.13 & 36.12 \\
\hline $\begin{array}{l}\text { Water costs in steel production, million U.S. dollars (in line with industrial } \\
\text { water tariffs) }\end{array}$ & 50.3 & 51.1 \\
\hline Water costs in coal mining, million U.S. dollars & 9.8 & 12 \\
\hline Total water recycling for own use, $\%$ & 93.3 & 93.3 \\
\hline Total air emissions (steel), kt & 396 & 382 \\
\hline Total air emissions (coal), kt & 403.2 & 429.7 \\
\hline Greenhouse gases, million tons of $\mathrm{CO}_{2}$ equivalent for steel sector & 27.34 & 26.58 \\
\hline Greenhouse gases, million tons of $\mathrm{CO}_{2}$ equivalent for coal sector & 11.72 & 12.98 \\
\hline \multicolumn{3}{|l|}{ Resource efficiency } \\
\hline Material intensity of steel production & 0.378 & 0.290 \\
\hline Material intensity of coal mining & 0.078 & 0.073 \\
\hline Energy intensity of steel production & 0.054 & 0.057 \\
\hline Energy intensity of coal mining & 0.025 & 0.029 \\
\hline
\end{tabular}

Table 4. The results of OJSC RUSAL Novokuznetsk activities for 2019-2020.

\begin{tabular}{|c|c|c|}
\hline Indicators & 2019 & 2020 \\
\hline \multicolumn{3}{|l|}{ Operating activities } \\
\hline Aluminum production, thousand tonnes & 215 & 215 \\
\hline Aluminum sales revenue, million U.S. dollars & 457.1 & 404 \\
\hline Material costs for aluminum production, million U.S. dollars & 240.3 & 217.6 \\
\hline Power consumption, million GJ & 27.2 & 26.0 \\
\hline Energy costs in aluminum production, million U.S. dollars & 176.8 & 169 \\
\hline \multicolumn{3}{|l|}{ Environmental activities } \\
\hline Aluminum production waste, million tonnes & 0.78 & 0.82 \\
\hline Metal waste recycling rate, $\%$ & 57 & 59 \\
\hline Cost of aluminum production waste, million U.S. dollars & 1.17 & 1.23 \\
\hline Water consumption in aluminum production, million $\mathrm{m}^{3}$ & 10.9 & 11.1 \\
\hline Industrial water costs, million U.S. dollars & 1.4 & 1.4 \\
\hline Total water recycling for own use, $\%$ & 93.2 & 92.6 \\
\hline Total air emissions (metal), kt & 0.56 & 0.62 \\
\hline Greenhouse gases, million tons of $\mathrm{CO}_{2}$ equivalent/a ton of aluminum & 2.03 & 2.04 \\
\hline \multicolumn{3}{|l|}{ Resource efficiency } \\
\hline Material intensity of aluminum production & 0.526 & 0.537 \\
\hline Energy intensity of aluminum production & 0.387 & 0.418 \\
\hline
\end{tabular}


In 2020, the volume of production and extraction dropped by 5671 thousand tons in physical terms versus 2019. As a result, the material costs decreased by 562 million U.S. dollars in value terms in steel production, and by 49 million U.S. dollars in coal mining. In 2020 , the material intensity indicator for steel production was 0.290 , being lower by 0.088 as compared to 2019. A factor analysis has revealed that a decrease in material intensity was caused by a decrease in material costs due to an increase in the use of secondary resources and a decrease in production. This is primarily owing to the environmental program implemented in the enterprise. In 2020, energy intensity decreased by 1.9 GJ per one ton of steel (25.6) versus 2019 (27.5). However, due to the increase in electricity prices, energy intensity indicators increased by 0.003 for steel and by 0.004 for coal.

Nevertheless, the material flows of JSC EVRAZ ZSMK were unbalanced in 2020. The total amount of resources consumed by the enterprise in steel production exceeded the value of production by 889 million U.S. dollars in value terms, taking into account the cost of waste.

In 2020, there was a decrease in material costs for aluminum production by 22.7 million U.S. dollars versus 2019 at a constant production volume. The material intensity indicator amounted to 0.537 , being higher by 0.011 as compared to 2019 . A factor analysis has revealed that an increase in material intensity was caused by a decrease in aluminum sales revenue by 115 U.S. dollars per ton due to the decline in the average price of aluminum sales in 2020. As a result, a decrease in revenue (53.1 million U.S. dollars) has invalidated a positive effect of reducing material costs by 22.7 million U.S. dollars. In 2020, energy intensity increased by 0.037 versus 2019 , despite the reduction of energy consumption by 1.2 million GJ.

In 2020, the material flows of OJSC RUSAL Novokuznetsk were unbalanced. The total amount of resources consumed by the enterprise in aluminum production exceeded the value of production by 18 million U.S. dollars in value terms, considering the cost of waste.

Similarly, the results of the operating and environmental activity of the construction company and the CHP plant, prior to entering the ecosystem, have been analyzed.

Provided that the main actors of OJSC RUSAL Novokuznetsk [54] and JSC EVRAZ ZSMK entered an industrial ecosystem, greenhouse gas emissions in the region would decrease by 8.32 million tons of $\mathrm{CO}_{2}$ equivalent, being $20 \%$ of the total emission (4.1 million tons of $\mathrm{CO}_{2}$ equivalent-for steel; 3.12 million tons of $\mathrm{CO}_{2}$ equivalent-for coal; 1.1 million tons of $\mathrm{CO}_{2}$ equivalent-for aluminum). Total energy consumption at the enterprises would decrease by 16.4 million GJ (14\%) due to the renewable energy of the CHP plant. Water consumption recycling would reach $98.3 \%$. The extent of mining waste recycling would increase from $38 \%$ to $51 \%$ and from 59 to $83 \%$ for metallurgical industries due to the entry of construction companies into the ecosystem. This would reduce the material intensity of aluminum production by 0.21 ; of coal mining-by 0.032 ; of steel production-by 0.16 .

The equation of the material flows of the ecosystem, created on the basis of circular economy models and calculated according to Formula (4), has shown that material flows in the ecosystem are balanced. The costs of raw materials and supplies, energy consumption, water consumption, that is, the amount of resources consumed in value terms are in the left part of the equation. On the right part, there is the cost of production value and waste from production and consumption.

The creation of an industrial ecosystem in Novokuznetsk would result in the elimination of area sources of pollution with dust, benzapilene, and other carcinogenic polycyclic aromatic hydrocarbons; the reduction of production and primary processing of natural resources; the increase in the amount of production in Novokuznetsk, which would advance regional sustainable development and enhance quality of life in the population.

In turn, upon having entered the ecosystem and significantly improved a number of environmental and resource efficiency indicators, JSC EVRAZ ZSMK would rise by five positions in the EGS ranking of Russian industrial companies, taking the 29th place, and OJSC RUSAL Novokuznetsk would improve its rating by six positions, taking the 23rd place [55]. 
This would attract additional investments from "green" investors to implement environmental projects in the circular ecosystem and the state program on transition to a low-carbon economy.

\section{Discussion and Conclusions}

In this work, the authors have made an attempt to develop a methodological approach to substantiate the socio-economic efficiency of enterprise performance within an industrial ecosystem in the context of a circular economy. The authors have proposed to assess the resource efficiency of industrial ecosystems from the standpoint of the balance of material flows. This approach has been verified via a case study of the industrial ecosystem in Novokuznetsk.

Based on the calculations, it has been evidenced that the creation of an industrial ecosystem in Novokuznetsk would eliminate area sources of pollution with dust, benzapilene, and other carcinogenic polycyclic aromatic hydrocarbons; reduce production and primary processing of natural resources; and increase the amount of production in Novokuznetsk, which would advance regional sustainable development and enhance quality of life in the population.

Thus, having used the proposed methodology, the prospects for the implementation of circular business models by enterprises within industrial ecosystems in order to increase the efficiency of resource use and sustainable economic development of the city and the region as a whole have been substantiated.

The interaction of actors within industrial ecosystems can be realized as an industrial symbiosis (it is a cooperation between enterprises, in which wastes or by-products of some enterprise are resources for another one); cooperation between participants in value chains takes the form of collaborative consumption of resources or associations of productservice systems.

The actors can implement recycling within industrial ecosystems in such diverse areas as:

$\checkmark \quad$ ecodesign (design of products for a long service life and their feasible modernization, reuse, repair, and refurbishment; product design based on environmentally sustainable and limited use of resources that ensures recycling to obtain high-quality secondary raw materials at the end of the product service life; elimination of hazardous materials from products and processes to ensure the purity of material flows);

$\checkmark \quad$ repair and refurbishment;

$\checkmark \quad$ recycling (processing of the maximum waste volume and nomenclature into highquality secondary raw materials; avoiding cascading; existence of well-functioning secondary raw materials markets; and avoiding mixing and contamination of materials; cascading in case of impossibility of recycling to obtain high-quality secondary raw materials).

The transformation of systems to ensure their sustainable development is a challenging issue [56]. Political will and adequate science-based support tools play a key role in securing or restraining the transition to a circular economy.

In our opinion, the role of government organizations as actors of industrial ecosystems should be realized through the provision of tools to support recycling strategies: reorientation of taxation from labor to natural resources and environmental pollution; rejection of subsidies to finance production (technologies) that have a negative impact on the environment; internationalization of environmental costs; introduction of deposit-refund systems; extension of producer responsibility, etc.

In general, it should be emphasized that companies, regulatory agencies, and the financial sector are increasingly interested in using methods that reflect the level of circularity of both individual enterprises and integrated associations, in particular, various industrial ecosystems.

Theoretical implications of the conducted research are in the proposed methodology, based on a system of indicators for operational, environmental and resource efficiency of an enterprise can be adapted for any industry or value chain to regularly measure 
their circularity and realize problems and business opportunities. Practical contribution of the research is that using this methodology, the enterprises will succeed in tracking their progress towards circularity in dynamics and use it to inform key stakeholders and investors interested in environmental, social, and corporate governance (ESG) factors. Currently, long-term investment strategies become unrealizable without taking into account ESG factors. Since the level of circularity of business and products turns out to be a factor to enhance competition, business communities (clusters, eco-industrial parks, industrial ecosystems, etc.) should apply this methodology to assess the level of circularity within value chains and to select key actors.

The methodology opens up promising opportunities, especially for industrial regions, because being the basis for competitiveness they are leading in the degradation of the environmental system.

At the same time, the methodology involves the use of a huge amount of primary data, which makes it burdensome to apply. The complexity of calculating a number of circularity indicators slows down the implementation of circular business models and causes difficulties in making effective management decisions.

Meanwhile, there are some limitations of the proposed methodology. Firstly, individual companies rather than the entire holdings often participate in industrial ecosystems. In this regard, it is hard to divide indicators in integrated reporting and distribute material resources and energy between the holding companies. Secondly, the balance equation of material flows is drawn up for industrial ecosystems operating on the principles of circularity, which implies a closed-loop movement of materials and flows. It is economically feasible to use the balance method for materials with a high level of recycling (from 70\%) and a high cost of primary waste. In this case, the amount of industrial waste disposed in the environment (not recycled) will tend to zero. Thirdly, prices for materials and resources indicated in U.S. dollars are based on the weighted average annual rate tariffs for Novokuznetsk.

Author Contributions: Conceptualization, formal analysis, writing-original draft preparation, data collection, data validation, and supervision, L.G.; writing-original draft preparation, data collection, data validation, first data analysis, and funding acquisition, N.S.; writing-original draft preparation, data collection, data validation, first data analysis, and funding acquisition, T.T.; data collection, data validation, and first data analysis, A.S. All authors have read and agreed to the published version of the manuscript.

Funding: This study was supported by the grant of the President of the Russian Federation for the young Russian scientists state support on scientific research «Balanced development of the territory based on industrial clusters in the context of theory of "smart specialisation" (grant number: MD-1823.2022.2).

Institutional Review Board Statement: Not applicable.

Informed Consent Statement: Not applicable.

Data Availability Statement: Not applicable.

Acknowledgments: The article was prepared within the framework of an agreement on scientific cooperation between Penza State University and the Institute for Regional Economy Problems of the RAS from 17.05.2021.

Conflicts of Interest: The authors declare no conflict of interest.

\section{References}

1. Order of the Government of the Russian Federation of October 29, 2021 No. 3052-r "On Approval of the Strategy for the Socio-Economic Development of the Russian Federation with a Low Level of Greenhouse Gas Emissions until 2050". Available online: https:/ / www.garant.ru/products/ipo/prime/doc/402894476/\#1000 (accessed on 16 October 2021).

2. European Commission. Communication from the Commission to the European Parliament, the Council, the European Economic and Social Committee and the Committee of the Regions, 'Closing the Loop - An EU Action Plan for the Circular Economy'. 2015. Available online: https:/ / eur-lex.europa.eu/legal-content/EN/TXT/?uri=CELEX:52015DC0614 (accessed on 15 October 2021). 
3. European Commission. Communication from the Commission to the European Parliament, the Council, the Economic and Social Committee and the Committee of the Regions "A new circular economy action plan for a cleaner and more competitive Europe". 2020. Available online: https:/ / eur-lex.europa.eu/legal-content/EN/TXT/?uri=COM:2020:98:FIN\&WT.mc_id=Twitter (accessed on 15 October 2021).

4. European Environment Agency (EEA). Circular by Design — Products in the Circular Economy, EEA Report No 6/2017. Available online: https:/ / www.eea.europa.eu/publications/circular-by-design (accessed on 16 October 2021).

5. Sverko Grdic, Z.; Krstinic Nizic, M.; Rudan, E. Circular Economy Concept in the Context of Economic Development in EU Countries. Sustainability 2020, 12, 3060. [CrossRef]

6. European Environment Agency (EEA). Paving the Way for a Circular Economy: Insights on Status and Potentials, EEA Report No 11/2019. Available online: https:/ / www.eea.europa.eu/publications/ circular-economy-in-europe-insights (accessed on 16 October 2021).

7. International Resource Panel. 2019. Available online: https://www.resourcepanel.org/news-events/international-resourcepanel-2019-highlights (accessed on 16 October 2021).

8. OECD. Global Material Resources Outlook to 2060 Economic Drivers and Environmental Consequences. 2018. Available online: https:/ / www.oecd.org/environment/waste/highlights-global-material-resources-outlook-to-2060.pdf (accessed on 23 September 2021).

9. Bobylev, S.N.; Solovyeva, S.V. Circular economy and its indicators for Russia. World New Econ. 2020, 14, 63-72. [CrossRef]

10. Federal Service for Supervision of Natural Resources. Actual Indicator Values for Integrated MSW Management System Federal Project for 2020. Available online: https:/ / rpn.gov.ru/activity/regulation/help/ (accessed on 13 November 2021).

11. Order of the Government of the Russian Federation of January 25, 2018 N 84-r On Approval of the Strategy for the Development of Industry for Processing, Utilization and Neutralization of Production and Consumption Waste for the Period until 2030. Available online: http://static.government.ru/media/files/y8PMkQGZLfbY7jhn6QMruaKoferAowzJ.pdf (accessed on 23 September 2021).

12. Guman, O.; Wegner-Kozlova, E. Impact of the regional development specifics on the system of circular economy assessment. E3S Web Conf. 2020, 208, 01004. [CrossRef]

13. Steffen, W.; Richardson, K.; Rockström, J.; Cornell, S.E.; Fetzer, I.; Bennett, E.M.; Biggs, R.; Carpenter, S.R.; de Vries, W.; de Wit, C.A.; et al. Faculty Opinions recommendation of Sustainability. Planetary boundaries: Guiding human development on a changing planet. Science 2015, 347, 1259855. [CrossRef]

14. Ellen McArthur Foundation. A New Textiles Economy: Redesigning Fashion's Future. 2017. Available online: https:// ellenmacarthurfoundation.org/a-new-textiles-economy (accessed on 23 November 2021).

15. Bocken, N.M.P.; de Pauw, I.; Bakker, C.; van der Grinten, B. Product design and business model strategies for a circular economy. J. Indust. Prod. Eng. 2016, 33, 308-320. [CrossRef]

16. Bocken, N.M.P.; Ritala, P. Six ways to build circular business models. J. Bus. Strat. 2021. Available online: https://doi.org/10.110 8/JBS-11-2020-0258 (accessed on 5 April 2021). [CrossRef]

17. Kirchherr, J.; Reike, D.; Hekkert, M. Conceptualizing the circular economy: An analysis of 114 definitions. Resour. Conserv. Recycl. 2017, 127, 211-232. [CrossRef]

18. Korhonen, J.; Nuur, C.; Feldmann, A.; Birkie, S.E. Circular economy as an essentially contested concept. J. Clean. Prod. 2018, 175, 544-552. [CrossRef]

19. Woolven, J. A New Measure of Business Success. Medium. 2021. Available online: https://medium.com/circulatenews/a-newmeasure-of-business-success-9e53b7aafafa (accessed on 5 November 2021).

20. Jacobides, M.G.; Cennamo, C.; Gawer, A. Towards a theory of ecosystems. Strat. Manag. J. 2018, 39, 2255-2276. [CrossRef]

21. Thomas, L.D.W.; Autio, E. Innovation Ecosystems. 2019. Available online: https://papers.ssrn.com/sol3/papers.cfm?abstract_ $\mathrm{id}=3476925$ (accessed on 15 October 2021).

22. Tolstykh, T.; Shmeleva, N.; Gamidullaeva, L. Evaluation of circular and integration potentials of innovation ecosystems for industrial sustainability. Sustainability 2020, 12, 4574. [CrossRef]

23. Aarikka-Stenroos, L.; Ritala, P.; Thomas, L.D.W. Circular economy ecosystems: A typology, definitions, and implications. In Research Handbook of Sustainability Agency; Edward Elgar Publishing: Cheltenham, UK, 2021.

24. Aarikka-Stenroos, L.; Ritala, P. Network management in the era of ecosystems: Systematic review and management framework Ind. Mark. Manag. 2017, 67, 23-36. [CrossRef]

25. Tansley, A.G. The use and abuse of vegetational concepts and terms. Ecology 1935, 16, 284-307. [CrossRef]

26. Frosch, R.A.; Gallopoulos, N.E. Strategies for manufacturing. Sci. America. 1989, 261, 144-152. [CrossRef]

27. Korhonen, J. Four ecosystem principles for an industrial ecosystem. J. Clean. Prod. 2001, 9, 253-259. [CrossRef]

28. Lowe, E.A.; Evans, L.K. Industrial ecology and industrial ecosystems. J. Clean. Prod. 1995, 3, 47-53. [CrossRef]

29. Chertow, M.R. Industrial symbiosis: Literature and taxonomy. Ann. Rev. Energy Environ. 2000, 25, 313-337. [CrossRef]

30. Gómez, A.M.M.; González, F.A.; Bárcena, M.M. Smart eco-industrial parks: A circular economy implementation based on industrial metabolism. Resour. Conserv. Recycl. 2018, 135, 58-69. [CrossRef]

31. Uusikartano, J.; Väyrynen, H.; Aarikka-Stenroos, L. Public actors and their diverse roles in eco-industrial parks: A multiple-case study. J. Clean. Prod. 2021, 296, 126463. [CrossRef]

32. Allenby, B.R. Implementing industrial ecology: The AT\&T matrix system. Interfaces 2000, 30, $42-54$ 
33. Tolstykh, T.; Gamidullaeva, L.; Shmeleva, N.; Lapygin, Y. Regional development in Russia: An ecosystem approach to territorial sustainability assessment. Sustainability 2020, 12, 6424. [CrossRef]

34. Tolstykh, T.; Gamidullaeva, L.; Shmeleva, N.; Woźniak, M.; Vasin, S. An assessment of regional sustainability via the maturity level of entrepreneurial ecosystems. J. Open Innov. Technol. Mark. Complex. 2020, 7, 5. [CrossRef]

35. Tolstykh, T.; Gamidullaeva, L.; \& Shmeleva, N. Approach to the formation of an innovation portfolio in industrial ecosystems based on the life cycle concept. J. Open Innov. Technol. Mark. Complex. 2020, 6, 151. [CrossRef]

36. Schroeder, P.; Anggraeni, K.; Weber, U. The relevance of circular economy practices to the sustainable development goals. J. Ind. Ecol. 2019, 23, 77-95. [CrossRef]

37. Moreno-Juez, J.; Vegas, I.J.; Gebremariam, A.T.; García-Cortés, V.; Di Maio, F. Treatment of end-of-life concrete in an innovative heating-air classification system for circular cement-based products. J. Clean. Prod. 2020, 263, 121515. [CrossRef]

38. Shojaei, B.; Abtahi, M.; Najafi, M. Chemical recycling of PET: A stepping-stone toward sustainability. Polym. Adv. Technol. 2020, 31, 2912-2938. [CrossRef]

39. Turken, N.; Cannataro, V.; Geda, A.; Dixit, A. Nature inspired supply chain solutions: Definitions, analogies, and future research directions. Int. J. Prod. Res. 2020, 58, 4689-4715. [CrossRef]

40. Corona, B.; Shen, L.; Reike, D.; Rosales Carreón, J.; Worrell, E. Towards sustainable development through the circular economy-A review and critical assessment on current circularity metrics. Resour. Conserv. Recycl. 2019, 151, 104498. [CrossRef]

41. OECD Environmental Performance Reviews: Denmark 2019. Available online: https://doi.org/10.1787/1eeec492-en (accessed on 5 November 2021).

42. Environmental Performance Index. 2018 EPI Results. Available online: https://epi.yale.edu/epi-countries (accessed on 5 November 2021).

43. Material Productivity and Waste. 2017, pp. 44-49. Available online: https://doi.org/10.1787/9789264268586-7-en (accessed on 5 November 2021).

44. Green Growth Indicators 2017. 2017. Available online: https://doi.org/10.1787/9789264268586-en (accessed on 5 November 2021).

45. Monitoring Framework - Circular Economy - Eurostat. Available online: https://ec.europa.eu/eurostat/web/circular-economy/ indicators (accessed on 15 October 2021).

46. Eurostat. Resource Efficiency Scoreboard. 2014. Available online: https://ec.europa.eu/environment/resource_efficiency/ documents/re_scoreboard_2014.pdf (accessed on 15 October 2021).

47. EU. Decision No 1386/2013/EU of the European Parliament and of the Council of 20 November 2013 on a General Union Environment Action Programme to 2020 Living Well, within the Limits of Our Planet, OJ L 354. 2013, pp. 171-200. Available online: https:/ / eur-lex.europa.eu/legal-content/EN/TXT/?uri=celex\%3A32013D1386 (accessed on 15 October 2021).

48. EC. Communication from the Commission to the European Parliament, the Council, the European Economic and Social Committee and the Committee of the Regions - Roadmap to a Resource Efficient Europe, COM(2011) 571 Final, Brussels. 2011. Available online: https:/ / eur-lex.europa.eu/legal-content/EN/TXT/?uri=CELEX:52011DC0571 (accessed on 15 October 2021).

49. Gilbert, T.F. Human Competence: Engineering Worthy Performance; Tribute Edition; Pfeiffer: Nashua, NH, USA, 2007.

50. Doranova, A.; Roman, L. Cooperation Fostering Industrial Symbiosis Market Potential, Good Practice and Policy Actions. Final Report. Teresa Domenech. University College London. Technopolis Group Matthew Smith, Irati Artola - Trinomics. Publications Office of the European Union. 2018. Available online: https://www.technopolis-group.com/wp-content/uploads/ 2020/02/Cooperation-fostering-industrial-symbiosis-market-potential-good-practice-and-policy-actions.pdf (accessed on 15 October 2021)

51. Savina, I.N.; Vodoleev, A.S.; Zakharova, M.; Domnin, K.I. Environmental policy of Novokuznetsk in the context of modern requirements for metallurgical industry development. Izv. Ferr. Met. 2020, 63, 512-520. [CrossRef]

52. Kuzbass Association of waste recyclers, Novokuznetsk, Russia. Available online: http:/ / wasteinfo.ru/ (accessed on 15 October 2021).

53. EVRAZ. Sustainability Report 2020. Available online: https://ar2020.evraz.com/en/meet-evraz (accessed on 15 October 2021).

54. RUSAL. Sustainability Report 2020. Available online: https://rusal.ru/upload/iblock/afa/afa0a5c7124865007de322e052db776c. pdf (accessed on 15 October 2021).

55. ESG Ranking of Russian Companies RAEX-Europe. Available online: https://raex-a.ru/rankingtable/ESG_ranking_companies/ 16/09/2021 (accessed on 15 October 2021)

56. Batova, N.; Wilts, H.; Dorozhko, S.; Lobanov, E.; Sysoev, S.; Tochickaja, I.; Shershunovich, I.; Shushkevich, A. Circular Economy: Conceptual Approaches and Tools for Their Implementation: A Monograph for Specialists of Government Bodies, Business and the Interested Public; Medisont: Minsk, Belarus, 2020. 